\title{
持続荷重下における端部鉄筋の抜け出しによる 鉄筋コンクリート片持梁の付加たわみ \\ ADDITIONAL DEFLECTION IN REINFORCED CONCRETE CANTILEVER BEAMS DUE TO SLIPPAGE OF BAR AT FIXED EDGE UNDER SUSTAINED LOADING
}

\author{
大野義照, 李 振 宝**, 鈴木計夫*** \\ Yoshiteru OHNO, Zhenbao LI and Kazuo SUZUKI
}

\begin{abstract}
The long-term loading tests of reinforced concrete cantilever beams were performed in order to understand and to clarify the mechanism of long-term deflection, especially the increase caused by the slippage of tension steel at the fixed edge on the reinforced concrete member after cracking. In the experiment six pieces of specimens were tested, and the slippage of the steel, crack widths and deflections were examined. Bond analysis equations for members on which different end bending moment acts were also presented. The analysis used the relationships between bond stress and slip proposed in the previous paper. Crack widths and deflections that occured by the slippage of steel were calculated by the bond analysis.
\end{abstract}

Kewords : long-term deflection, crack width, slippage of tension steel, bond analysis, cantilever bean, sustaind loading

長期たわみ，ひひ割れ幅，鉄筋の抜け出し，付着解析，片持ち梁，持続荷重

\section{1．まえがき}

鉄筋コンクリート（以下ＲＣと略記）のスラブでは， ひび割れによる損傷や長期荷重による過大なたわみが問

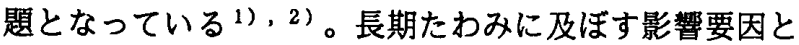
して，(1)コンクリートのクリープと収縮，(2)曲げひび割 れによる剛性低下, (3)固定支持端からの鉄筋抜け出しな どが考えられる。日本建築学会の $\mathrm{R} \mathrm{C}$ 構造計算規準 ・同 解説の付録 ${ }^{3)}$ にはコンクリートのクリープ，乾燥収縮お よび曲げひび割れの影響を考慮した長期たわみ計算法が 示されている。しかし，端部鉄筋の抜け出しの影響につ いては無視できないとしながらも定量的な評価ができる までには至っていないために考虑されていない。

この鉄筋の拔け出しによる付加たわみについてはこれ までにいくつかの報告がなれているが，抜け出し量の 算定が重要な問題の一つとなっている。東・小森4) はス ラブのたわみを各部分の剛性によるたわみと鉄筋の抜け 出しによるたわみとの和として計算している。この報告 はスラブの端部にひび割れが発生した後の抜け出しによ
る付加たわみが無視できないほど大きいことを指摘した 最初の研究であり，その意義は大きい。しかし，抜け出 しの算定には定着部における付着応力として平均付着応 力を用いているなどの問題が残されている。小柳5)らは スラブの長期たわみに関する研究の一環として片引き試 験体の持続載荷実験を行い，得られた鉄筋の抜け出し量 を用いてスラブ端部での回転角を評価し付加たわみを計 算している。しかし，片引き試験から得られた鉄筋の抜 け出しの実験式は両引きの場合には適用できない。岩原 6)，7) は抜け出しによる付加たわみを厳密に定式化し， スラブからの鉄筋の拔け出しの影響を付着応力て〜すべ り $\mathbf{s}$ 関係での付着弾性剛性を用いて, 弾塑性たわみ角式 の中に組み入れている。しかし，抜け出し量を求める片 引きモデルでは引張力が一端から鉄筋に作用し， R Cプ リスムの他端に等分布反力が作用しているとするモデル 化の方法および定着長さは常時荷重域で R C 規準に規定

\footnotetext{
注：本文の一部は文献14），15）に発表している。

* 大阪大学工学部建築工学科 助教授・工博

**大阪大学大学院建築工学専攻 大学院生

*** 大阪大学工学部建築工学科 教授 $\cdot$ 工博
}

Assoc. Prof., Dept. of Architecture, Faculty of Engneering Osaka Univ., Dr. Eng.

Graduate Student, Dept. of Architecture, Faculty of Engineering, Osaka Univ.

Prof., Dept. of Architecture, Faculty of Engineering, Osaka Univ., Dr. Eng. 
されている值に決められているなど，解析上に問題が残 されている。また，井野 ${ }^{8)}$ らや岡田 ${ }^{9)}$ も鉄筋抜け出しに よるたわみの計算法を提示しているが，鉄筋抜け出しは 小柳の実験式をもとに簡略化された算定式を用いている。

本論文では，スラブや梁の端部ひび割れ幅は固定端 (スタブ部分) からの鉄筋抜け出しとスラブや梁部分か らの抜け出しからなると考え，それらの抜け出し量を算 定するため，曲げ材の両端に異なる曲げモーメントが作 用した場合の付着解析モデルを提示した。

次に，スラブの長期たわみ特に端部鉄筋の抜け出しに よるたわみのメカニズムを解明し，その増加量をより的 確に把握するために，6体の片持梁の持続載荷実験を行 い，その端部鉄筋の抜け出しによるひび割れ幅およびた わみの増加に対する影響を調べるとともに，本論に提示 した付着解析法により端部ひび割れ幅および端部鉄筋の 抜け出しによる付加たわみを解析し，その適合性を示し た。

\section{R C引張材の付着解析}

2. 1 解析モデル

（1）解析モデル

付着解析とは鉄筋とコンクリートの一部分を付着解析 モデルとしてとり出し，その鉄筋とコンクリート間の付 着応力，相対すべり量および鉄筋ひずみの分布を解析的 に定量化することであり，既往のモデル化の方法には主 として次の二つがある。一つは等曲げ部材の引張側ある いは中柱 (中梁) と梁（スラブ）の接合部をモデル化し た両引モデル6，１0），11）である。他の一つは隅柱（隅 梁）と梁（スラブ）の接合部をモデル化した片引モデル 6)である。これらの方法はいずれも䈯密には通常の曲げ モーメント勾配のある部材には適用できない。そこで， 部材両端に異なる曲げモーメントが作用した場合にも適 用できる図 1 に示すような付着解析モデルを提案する。 図中の弾性域，塑性域はそれそれて〜 $\mathrm{s}$ 関係を図 2 のよ うに弾塑性曲線で仮定した場合の○AおよびAB域に対 応するものである。全長にわたる等分布せん断力 $\mathrm{q}$ は部 材両端の引張力の差により次式で与える。

$$
\mathrm{q}=\left(\mathrm{P}_{\mathrm{s}_{1}}-\mathrm{P}_{\mathrm{s}_{2}}\right) / \mathrm{L}
$$

特例として,

(a) 両引モデル : $P_{\mathrm{S}_{1}}=\mathrm{P}_{\mathrm{S} 2}$

(b). 片引モデル : $\mathrm{P}_{\mathrm{s} 2}=0$

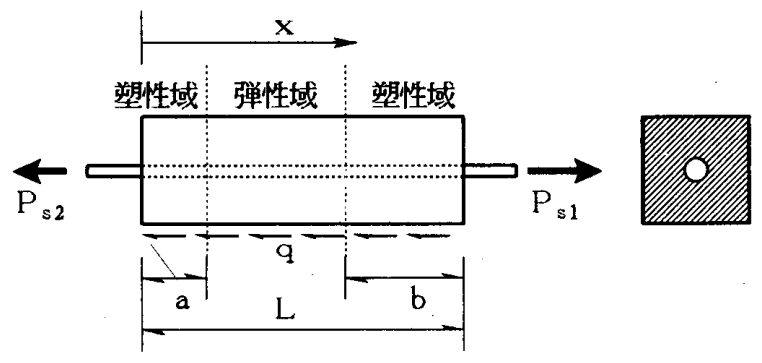

図 1 付着解析モデル
これによって両引，片引を含めた付着解析モデルの一般 化ができる。

（2）基本仮定

上記の付着解析モデルに対し，次のことを仮定する。

（a）軸方向変形のみを考虑し，それと直角方向のせん 断変形を無視する。

（b）持続荷重下における付着応力 $\tau$ 〜相対すべり $\mathrm{s}$ 関 係を図 2 に示すように完全弾塑性近似曲線とする。

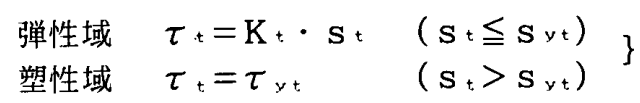

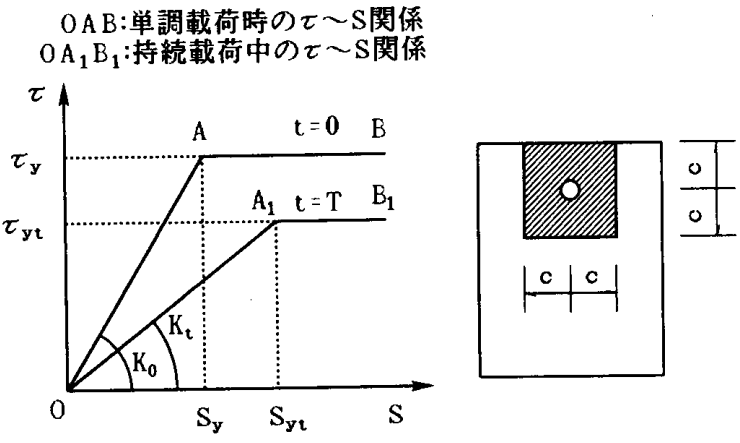

図2 $\tau \sim \mathrm{s}$ 関係

図 3 解析用有効断面

（c）梁およびスタブ部分を解析する際，引張鉄筋と コンクリートの図心とが一致するコンクリート部分が引

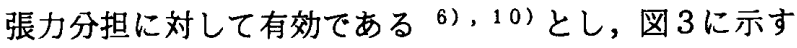
ハッチ部分を解析用コンクリート引張有効断面とする。

2 . 2 微分方程式および解

(1) 微分方程式

図 1 に示した両引材において，時刻 $\mathrm{t}$ の時における両 端に作用する力をそれそれ $\mathrm{P}_{\mathrm{S} 1}(\mathrm{t}), \mathrm{P}_{\mathrm{S} 2}(\mathrm{t})$ ，その間に 作用するせん断力を $q(t)$ とすると，既報 ${ }^{11)}$ と同じよう な方法で次の微分方程式が誘導できる。

$\frac{d^{2} S_{x}(t)}{d x^{2}}=\frac{1+n^{-} p}{E_{s} A_{s}} \cdot U \cdot \tau_{x}(t)-\frac{q(t)}{E_{c}{ }^{-} A_{c}}$

ただし: $q(t)=\left(P_{s 1}(t)-P_{s 2}(t)\right) / L, n^{-}=E_{s} / E_{c}$ $\mathrm{E}_{\mathrm{c}} \cdot=\mathrm{E}_{\mathrm{c}} /(1+0.5 \phi), \quad \mathrm{p}=\mathrm{A}_{\mathrm{s}} / \mathrm{A}_{\mathrm{c}}$ $S_{x}(t)$ : 時刻 $t$ の時 $x$ 位置における鉄筋とコンクリート の相対すべり

$\mathrm{E}_{\mathrm{s}}, \mathrm{A}_{\mathrm{s}}, \mathrm{U}$ : 鉄筋のヤング係数, 断面積, 周長

$\mathrm{E}_{\mathrm{c}}, \mathrm{A}_{\mathrm{c}}, \phi:$ コンクリートのヤング係数, 断面積, ク リープ係数, $\mathrm{E}^{-}{ }_{\mathrm{c}}$ の式において応力変化を考慮して 0.5を乗じている。

上式は両端に異なる引張力作用した持続荷重下におい て両引モデルに関する付着の基礎式である。 $\tau_{x}(t)=f$ $\left(s_{x}(t)\right)$ という付着応力 $\tau$ 〜ずり $s$ 関係を与えれば， 境界条件を与えて上式を解くことによってすべり分布が 
求まり，それにより付着応力や鉄筋ひずみの分布が求ま る。

\section{（2）一般解}

式(1)の $\tau \sim \mathrm{s}$ 関係を用いて上記の微分方程式(2)を解 けば， $S_{x}(t) ， P_{x}(t)$ は次のように求まる。

塑性域 $\mathrm{a}: \mathrm{S}_{\mathrm{xpa}}(\mathrm{t})=\frac{1}{2} \cdot \gamma_{\mathrm{a}} \cdot \mathrm{x}^{2}+\mathrm{C}_{1} \cdot \mathrm{x}+\mathrm{C}_{2}$

$$
P_{x p y}(t)=P_{s 2}(t)-U \cdot \tau_{y t} \cdot x
$$

弾性域: $\mathrm{S}_{\times \mathrm{e}}(\mathrm{t})=\mathrm{C}_{3} \mathrm{e}^{\alpha \mathrm{x}}+\mathrm{C}_{4} \mathrm{e}^{-\alpha \mathrm{x}}+\frac{\beta}{\alpha^{2}}$

$$
\begin{aligned}
P_{x e}(t) & =\frac{E_{s} A_{s}}{1+n^{-} p}\left(\alpha C_{3} e^{\alpha x}-\alpha C_{4} e^{-\alpha x}\right. \\
& \left.+\frac{P_{s 2}(t)}{E_{0} A_{c}}+\beta \cdot x-S_{h}(t)\right)
\end{aligned}
$$

塑性域 $b: S_{x p b}(t)=\frac{1}{2} \cdot \gamma_{b} \cdot x^{2}+C_{5} \cdot x+C_{6}$

$$
P_{x p b}(t)=P_{s 1}(t)-U \cdot \tau_{y t} \cdot(L-x)
$$

ただし : $\alpha^{2}=\frac{1+\mathrm{n}^{-} \mathrm{p}}{\mathrm{E}_{\mathrm{s}} \mathrm{A}_{\mathrm{s}}} \cdot \mathrm{U} \cdot \mathrm{K}_{\mathrm{t}}$

$$
\beta=\frac{q(t)}{E_{c}^{\prime} A_{c}}
$$

$$
\gamma_{n}=-\frac{1+n^{\prime} p}{E_{s} A_{s}} \cdot U \cdot \tau_{y t}-\beta
$$

$$
\gamma_{b}=\frac{1+\mathrm{n}^{-p} \mathrm{p}}{\mathrm{E}_{\mathrm{s}} \mathrm{A}_{\mathrm{s}}} \cdot \mathrm{U} \cdot \tau_{y_{\mathrm{t}}}-\beta
$$

$S_{h}(t)$ : コンクリートの乾燥収縮ひずみ, $S_{x p a}(t)$, $S_{x e}(t), S_{x p b}(t) お よ ひ ゙ P_{x p a}(t), P_{x e}(t), P_{x p b}(t):$ それそれ時刻 $\mathrm{t}$ の時の塑性域 $\mathrm{a}$, 弾性域, 塑性域 $\mathrm{b} の \mathrm{x}$ 位置におけるすべりおよび鉄筋に作用する引張力 上式において，次の境界条件

$$
\begin{array}{lll}
x=0: & P_{x p a}(t)=P_{s i}(t) & \\
x=L: & P_{x p b}(t)=P_{s i}(t) & \\
x=a: & S_{x p a}(t)=-S_{y t}, & S_{x e}(t)=-S_{y t} \\
x=L-b: & S_{x e}(t)=S_{y t}, & S_{x p b}(t)=S_{y t}
\end{array}
$$$$
\text { より, 積分定数が求まる。 }
$$$$
C_{1}=\frac{P_{s 2}(t)}{E_{s} A_{s}}+S_{h}(t)
$$

$\mathrm{C}_{2}=-\mathrm{S}_{\mathrm{yt}}-\frac{1}{2} \quad \gamma_{\mathrm{a}} \cdot \mathrm{a}^{2}-\mathrm{C}_{1} \cdot \mathrm{a}$

$C_{3}=\frac{\left(S_{v t}+\beta / \alpha^{2}\right) \cdot e^{-\alpha(L-b)}+\left(S_{y t}-\beta / \alpha^{2}\right) \cdot e^{-\alpha a}}{e^{\alpha(L-a-b)}-e^{-\alpha(L-a-b)}}$

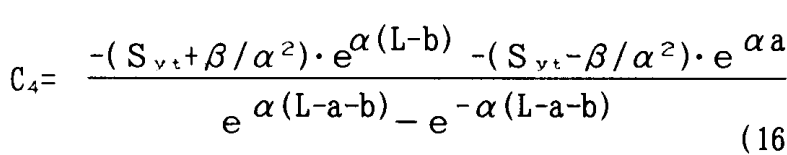

$C_{5}=\frac{P_{s 1}(t)}{E_{s} A_{s}} \cdot S_{h}(t)-\gamma_{b} \cdot L$

$\mathrm{C}_{6}=\mathrm{S}_{\mathrm{yt}}-\frac{1}{2} \gamma_{\mathrm{b}} \cdot(\mathrm{L}-\mathrm{b})^{2}-\mathrm{C}_{5} \cdot(\mathrm{L}-\mathrm{b})$

塑性域長さ $\mathrm{a}, \mathrm{b}$ は次の連続条件

$$
\begin{aligned}
& x=a, P_{x p a}(t)=P_{x e}(t) \\
& x=L-b, P_{x e}(t)=P_{x p b}(t)
\end{aligned}
$$

より

$$
\begin{aligned}
& \alpha \mathrm{C}_{3} \cdot \mathrm{e}^{\alpha \mathrm{a}}-\alpha \mathrm{C}_{4} \cdot \mathrm{e}^{-\alpha \mathrm{a}-\gamma_{\mathrm{a}} \cdot \mathrm{a}-\mathrm{C}_{1}}=0 \\
& \begin{array}{r}
\alpha \mathrm{C}_{3} \cdot \mathrm{e}^{\alpha(\mathrm{L}-\mathrm{b})} \alpha \mathrm{C}_{4} \cdot \mathrm{e}^{-\alpha(\mathrm{L}-\mathrm{b})} \\
-\gamma_{\mathrm{b}} \cdot(\mathrm{L}-\mathrm{b})-\mathrm{C}_{5}=0
\end{array}
\end{aligned}
$$

から求まる。

特例 $(\mathrm{a})$ 両引の場合 $q(\mathrm{t})=0$ としてよい。

(b) 片引の場合 $q(t)=\mathrm{P}_{\mathrm{S}_{1}}(\mathrm{t}) / \mathrm{L}$ とし, 解析 試験体長さ Lおよび塑性域長さbは次の条件

$$
\begin{aligned}
& x=L-b, \quad P_{x e}(t)=P_{x p b}(t) \\
& x=0, \quad P_{x e}(t)=0
\end{aligned}
$$

\begin{tabular}{|c|c|c|c|c|c|}
\hline 験 & 試験体名 & $\begin{array}{l}\text { 端部鉄筋 } \\
\text { 持続応力 } \\
\left(\mathrm{kgf} / \mathrm{cm}^{2}\right)\end{array}$ & $\begin{array}{c}\text { 持続荷重 } \\
\text { (tf) }\end{array}$ & $\begin{array}{l}\text { コンクリー } \\
\text { 卜目標強度 } \\
\left(\mathrm{kgf} / \mathrm{cm}^{2}\right)\end{array}$ & $\begin{array}{l}\text { シール } \\
\text { の有無 }\end{array}$ \\
\hline \multirow{2}{*}{ I } & $L-I-1$ & \multirow{2}{*}{2000} & \multirow{2}{*}{0.9} & \multirow{2}{*}{400} & \multirow{2}{*}{ 無 } \\
\hline & $\mathrm{L}-\mathrm{I}-2$ & & & & \\
\hline \multirow{4}{*}{ II } & TN & \multirow{2}{*}{2000} & \multirow{2}{*}{1.0} & \multirow{4}{*}{280} & 無 \\
\hline & $\mathrm{TS}$ & & & & 有 \\
\hline & $\mathrm{L}-\mathrm{II}-1$ & 1000 & 0.5 & & \multirow{2}{*}{ 無 } \\
\hline & L-II-2 & 2200 & 1.1 & & \\
\hline
\end{tabular}

および定着条件 : $\mathrm{x}=0, \mathrm{~S}_{\mathrm{x} \text { e }}(\mathrm{t})=\mathrm{S}_{0} \quad\left(\mathrm{~S}_{0}\right.$ は結果へ の影響か殁どない程度に 0 に近い值で,一般に $0.001 \mathrm{~cm}$ 程 度がよいとされている10)）から求まる。

\section{3. 実験概要}

\section{1 試験体形状と種類}

試験体の形状および配筋状況をそれそれ図 4 および困 5 ( a )，(b)にその種類を表 1 に示す。試験体は大きく 分けてスタブの片側にのみ片持ち梁を有する試験体（L 型梁と呼ぶ）とスタブの両側に片持ち梁を有する試験体 （T型梁と呼ぶ）からなる。

実験 I では十分な定着長さを持ち，鉄筋の折曲げ部の ない L型の試験体を 2 体作製し，端部鉄筋の抜け出しに よる付加たわみの基本性状を調べた。さらにより詳細に その性状を把握するため, 実験 II では T 型および折曲げ 部のある L 型の 2 種類の片持梁を 2 体ずつ作製し，試験 変数は $\mathrm{T}$ 型梁では乾燥収縮量（エポキシ樹脂の塗布に

表 1 試験体の種類 


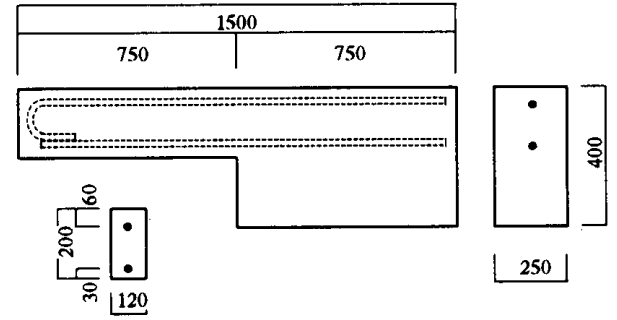

図4＼cjkstart試験体の形状および配筋状況（実験 I ）
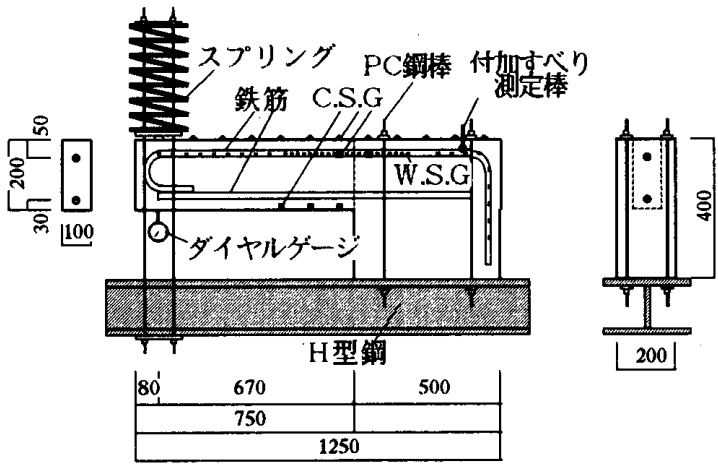

(a)

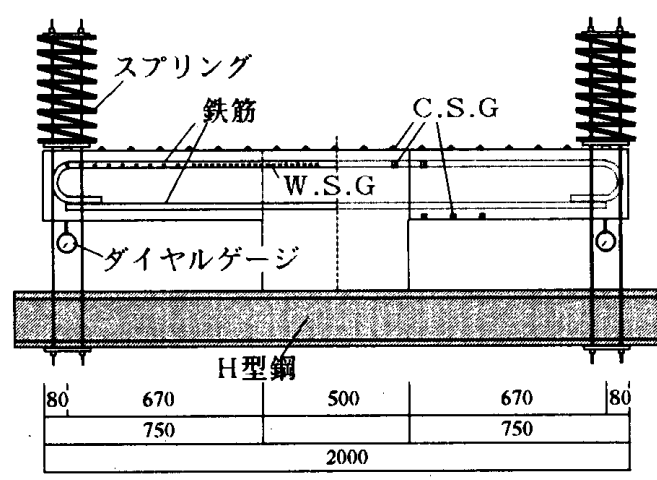

(b)

図 5 試験体の形状，配筋状況および持続載荷装置 （実験II）

よって制御）とし，L型では端部持続鉄筋応力とした。 また，実験 I，実験IIに用いたコンクリートの載荷時の 目標強度はそれそれ 400 と $280 \mathrm{kgf} / \mathrm{cm}^{2}$ で, 引張鉄筋のかぶ り厚さはそれぞれ 6 と $5 \mathrm{~cm}$ とした。

表 2 コンクリートの力学的性質

\begin{tabular}{|c|c|c|c|c|}
\hline 験 & $\begin{array}{l}\text { 材令 } \\
\text { (日) }\end{array}$ & $\begin{array}{l}\text { 圧縮強度 } \\
\left(\mathrm{kgf} / \mathrm{cm}^{2}\right)\end{array}$ & $\begin{array}{l}\begin{array}{l}\text { 割裂強度 } \\
\left(\mathrm{kgf} / \mathrm{cm}^{2}\right)\end{array}\end{array}$ & $\begin{array}{l}\text { ヤング係数 } \\
\left(\mathrm{kgff} / \mathrm{cm}^{2}\right)\end{array}$ \\
\hline I & $\begin{array}{r}14 \\
28 \\
292\end{array}$ & $\begin{array}{l}396 \\
426 \\
459\end{array}$ & $\begin{array}{l}32.2 \\
38.3 \\
32.9\end{array}$ & $\begin{array}{l}2.74 \times 10^{5} \\
2.89 \times 10^{5} \\
2.90 \times 10^{5}\end{array}$ \\
\hline II & $\begin{array}{r}28 \\
442 \\
749\end{array}$ & $\begin{array}{l}285 \\
296 \\
308\end{array}$ & $\begin{array}{l}19.8 \\
26.7 \\
25.4\end{array}$ & $\begin{array}{l}2.46 \times 10^{5} \\
2.36 \times 10^{5} \\
2.40 \times 10^{5}\end{array}$ \\
\hline
\end{tabular}

\section{2 使用材料}

使用したコンクリートは実験 I では早強ポルトラント セメント，山砂拉よび最大粒径 $15 \mathrm{~m} \mathrm{~m}$ の砕石を用いた コンクリートで，実験IIでは普通ポルトラントセメント， 山砂および最大粒径 $15 \mathrm{~m}$ mの砕石を用いたレディーミク ストコンクリートである。表 2 にコンクリートのカ学的 性質を示す。

鉄筋は図 6 に 示すように，鉄 筋ひずみを測定 するためのワイ ヤ・ストレ イン・ゲージ

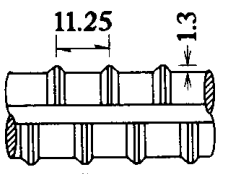

$1.0 \quad 3.5$

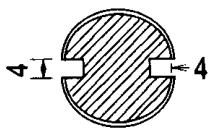

加工断面 单位: $\mathrm{m} \mathrm{m}$

図6 鉄筋ふしおよび断面形状

(W. S. G)

を貼付するため綐りブを削って溝加エした横ふし異形鉄 筋D 19（S D 345）を用いた。

3.3 載荷方法と測定項目

載荷方法も前揭の図 5（a），（b ）に示す。実験 I の載荷方法は実験 II のL型梁と同じである。L型梁のH 型鋼への固定は締め付け力の影響が生じないように固定 用 $\mathrm{P} \mathrm{C}$ 鋼棒を鉄筋から $6 \mathrm{~cm}$ 離した。長期たわみによる 持続荷重の減少を防ぐためスブリングを介して載荷した。 鉄筋ひずみはスタブと梁の接合部付近では 2 子し $(2.25 \mathrm{c} \mathrm{m})$ ，その他では 4 ふし $(4.5 \mathrm{c} \mathrm{m})$ 間隔に貼付 したW.S.Gにて，ひび割れ幅は梁上面およひ側面（端 部，鉄筋位置）に貼付したコンタクト・ストレイン・ ケ゚ージ（C.S.G）にて測定した。たわみは載荷点にお いてダイヤルゲージにて測定した。また，実験II し 型 試験体のスタブ部鉄筋折り曲げ部分のすべりを測定する ために，折り曲げの手前において，鉄筋に固定した棒の 先端の移動をC.S.Gにて測定した。なお，コンクリー トの乾燥収縮は片持梁のスタブ部分および梁部分と同じ 形状の試験体において測定し，クリーブは実験 Iでは断 面 $12 \times 12 \mathrm{c} \mathrm{m}$, 実験 II では断面 $10 \times 10 \mathrm{c} \mathrm{m}$ のコントロー ル試験体において圧縮クリープ性状（圧縮応力はそれそ れ42と60kgf $/ \mathrm{cm}^{2}$ である）を調べた。シールした試験体を 除きそれらの結果を図 7 に示す。図中の曲線は最小 2 乗 法で求めた近似曲線である。なお，載荷経過日数450日に おけるシールされた試験体の乾燥収縮ひずみは2.0×10-4, クリープ係数は1.5であり，それそれシールされていない 試験体の約 $1 / 3$ と $1 / 2$ である。

\section{4. 実験結果および考察}

4. 1 解析に用いる $\tau \sim \mathrm{s}$ 関係

実験結果の考察の前に，解析に用いる $\tau \sim \mathrm{s}$ 関係を設 定する。それを用いて前述の付着解析法により鉄筋ひず み分布，端部ひび割れ幅および端部鉄筋の抜け出しによ る付加たわみを解析した。梁のひび割れ間の部分の解析 


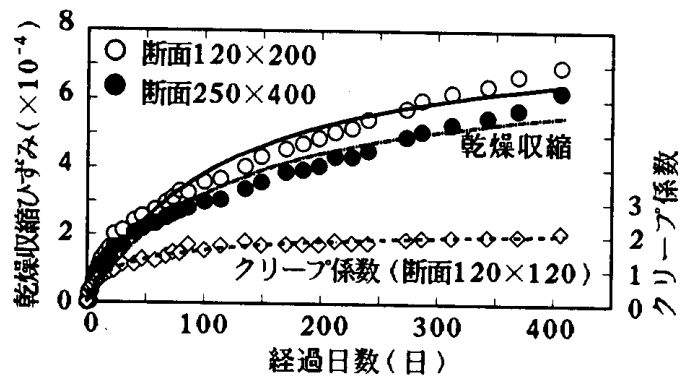

(a) 実験 I

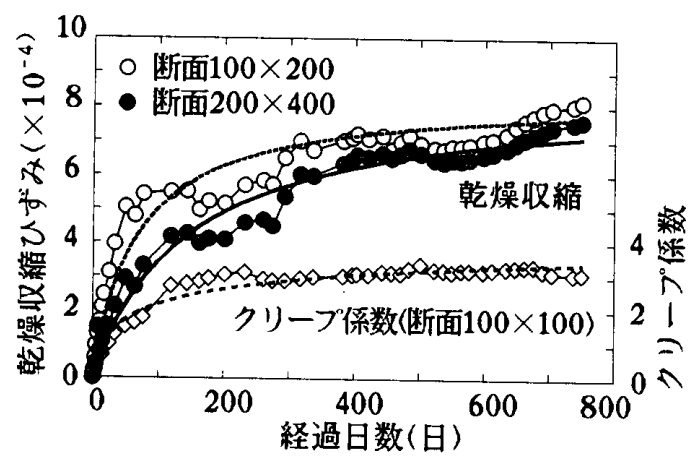

(b) 実験 II

困 7 コンクリートの乾燥収縮およびクリープ係数

表 $3 \tau \sim \mathrm{s}$ 関係の設定

\begin{tabular}{|c|c|c|c|c|}
\hline \multirow{5}{*}{ 茷 } & 実䮦 & 部材 & $\begin{array}{c}\tau_{y 0} \\
\left(\mathrm{kgg} / \mathrm{cm}^{2}\right)\end{array}$ & $\begin{array}{c}\mathrm{K}_{0} \\
\left(\mathrm{kgf} / \mathrm{cm}^{3}\right)\end{array}$ \\
\hline & \multirow[b]{2}{*}{1} & 梁 & 43.2 & 10400 \\
\hline & & スタブ & 56.1 & 8900 \\
\hline & \multirow{2}{*}{ II } & 梁 & 36.0 & 10700 \\
\hline & & スタブ & 46.8 & 8900 \\
\hline & \multicolumn{4}{|c|}{$\begin{aligned} \tau_{y_{t}} & =\mathrm{k}_{1} \cdot \tau_{v_{0}} \\
\mathrm{~K}_{\mathrm{t}} & =\mathrm{k}_{2} \cdot \mathrm{K}_{\mathrm{J}} \\
\mathrm{k}_{1} & =0.75 \\
\mathrm{k}_{2} & =\left(0.25+0.5 \cdot \mathrm{t}^{0.2}\right) / \mathrm{t}^{0.2} \\
\mathrm{t} & \text { は持続載荷の経過日数 }\end{aligned}$} \\
\hline
\end{tabular}

には前述の付着解析法を， $\mathrm{T}$ 型 梁および L 型梁のスタブ部分 の解析にはその特例の両引き モデルおよび片引きモデルを 用いた。既報 ${ }^{11}$ )の両引き試 験体の単調および持続載荷試 験結果を参考にし，鉄筋の種 類，コンクリート強度，およ び部材断面を考慮して，て〜 $\mathrm{s}$ 関係を表 3 に示すように設 定した。

単調載荷時において実験 I の梁部分, スタブ部分および 実験IIの梁部分ではそれそれれ 鉄筋種, コンクリート強度お よび断面がほぼ一致する既報
11) の両引試験体 II $-1, \mathrm{II}-5$ および I - 1の $\sim \mathrm{S}$ 関 係を，実験 IIのスタブ部分の ${ }_{\mathrm{y} 0}$ は断面の大きさを考慮 して両引試験体 I -1 の $\tau_{\mathrm{y} 0}$ にII -5 とII -1 の $\tau_{\mathrm{y} 0}$ の 比率を乗じたものを， $\mathrm{K}_{0}$ は両引試験体 II -5 の值を用い た。持続載荷中における $\tau \sim \mathrm{S}$ 関係の変化は既報 ${ }^{11)}$ に報 告した両引試験結果をそのまま用いた。

4. 2 鉄筋ひずみ分布

図 8 に試験体 L - I - 1 の単調および持続載荷中にお ける鉄筋ひずみ分布を示す。なお，試験体L－I－2の 鉄筋ひずみ分布は L - I - 1 とほぼ同じなので，紙数の 関係で省略する。図中の記号は実測值で，細実線部分は 単調載荷中, 太実線および点線, 破線は持続載荷中の解

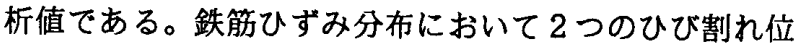
置の間には谷が形成され，コンクリートの付着効果が示 されている。持続載荷開始後一日目に，ひび割れ位置の 鉄筋ひずみは圧縮側コンクリートのクリープによって若 干增え，他の位置ではさらに付着応力の緩和によって增 大するが, その後はほとんど変わらない。解析值は単調 載荷時, 持続載荷中とも実測值をほほ捉えている。なお, 鉄筋ひずみ分布を求める際に，ひび割れ位置の鉄筋ひず みには実測值を用い,ひび割れの両側の 1 子し間は付着 がないものとして解析した。

4.3 端部鉄筋の抜け出しによる付加たわみの基本性 状 (実験 I)

（1）単調載荷時の端部ひび割れ幅とたわみ

a. 端部ひび割れ幅

図 9 に試験体 L - I - 1 の初載荷時の荷重 $\mathrm{P}$ と鉄筋位 置側面における端部ひび割れ幅Wとの関係を示す。ひび 割れは荷重0.4tで生じ, 以後荷重の増加に従ってほほ直 線的に増加し, 単調載荷完了荷重 0.9 tの時, $0.22 \mathrm{~mm}$ (試験 体 L - I - 2 は0.23mm) である。

端部ひび割れ幅は鉄筋のスタブ部分からの抜け出しと 梁部分からの抜け出しによって生じると考え，スタブ内

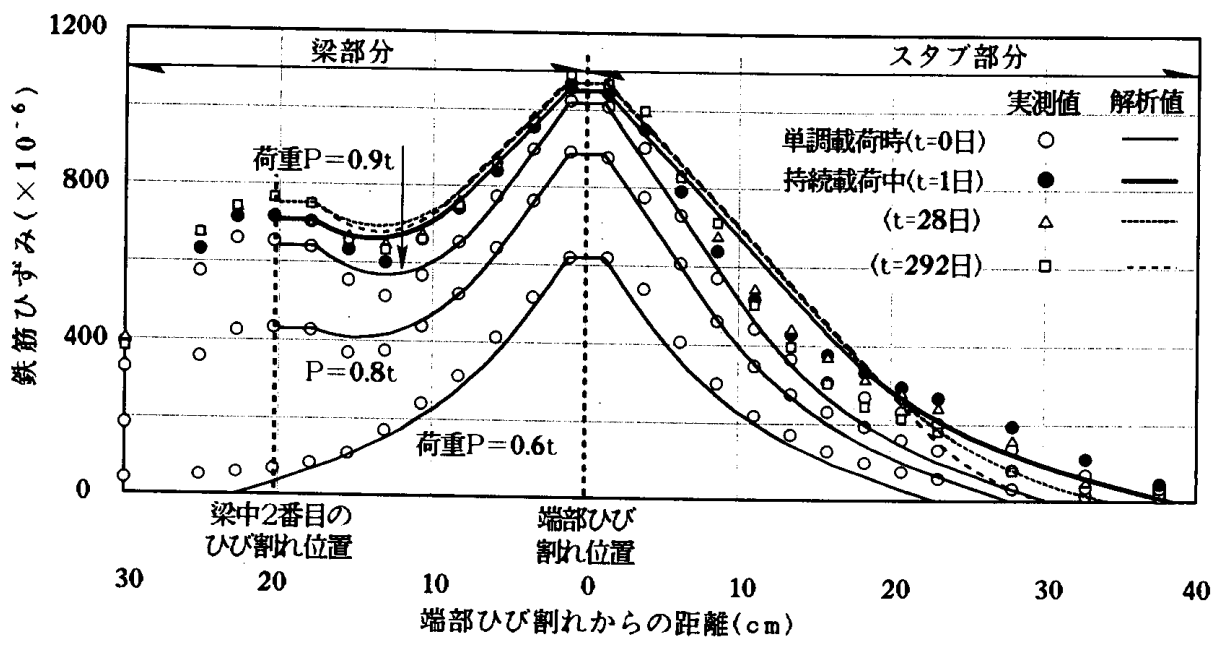

図8鉄筋ひずみ分布（L-I-1 試験体） 


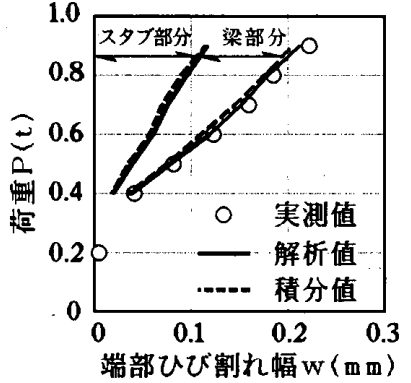

図 9 初載荷時の $\mathrm{P} \sim \mathrm{w}$ 関係

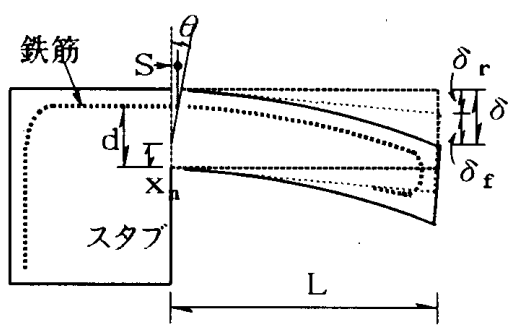

図 10 片持ち梁のたわみ

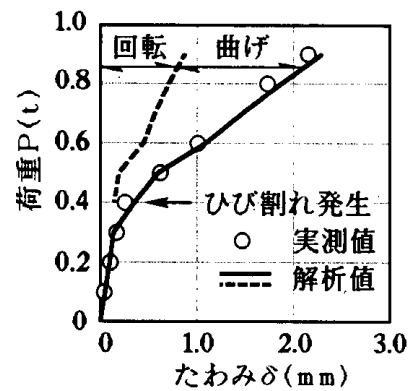

図 11 初載荷時の $\mathrm{P} \sim \delta$ 関係
の実測された鉄筋ひずみを積分して求めたスタブ部分か らの抜け出しと, 端部ひび割れ位置から端部ひび割れと その次のひび割れとの間の鉄筋ひずみが最も小さい位置 までの鉄筋ひずみ（図8参照）を積分して算出した梁部 分からの鉄筋の抜け出しの計算値を破線で示す。実線は 前述の付着解析法による解析值である。解析值によると， スタブ部分における鉄筋の抜け出しは端部ひび割れ幅の 約 $55 \%$ と大きな割合を占めている。

b.たわみ

片持ち梁のたわみは図 10 に示すように曲げモーメン トによる梁の曲げたわみ $\delta_{\mathrm{P}} に$ ，スタブからの抜け出しに よる回転たわみ $\delta_{r}$ が加わる。図 11 に試験体 L - I - 1 の初載荷時の荷重 $\mathrm{P} \sim$ たみ $\delta$ 関係を示す。端部ひび割 れの発生後, たわみが大きく増大し，単調載荷完了荷重 0.9tの時，1.92mm（L-I-2は2.15mm）である。

同図中の破線は端部鉄筋の抜け出しによって生じた回 転付加たわみ $\delta$ 它，実線は $\delta_{\mathrm{r}}$ と梁の曲げによるたわみ $\delta_{\mathrm{f}}$ の和を表している。 $\delta_{\mathrm{f}}$ はA C I コード12)に提案さ れている有効断面二次モーメントを用い，モールの定理 より計算した。端部筋の拔け出しによる回転付加たわみ $\delta_{\mathrm{r}}$ は, スタブ部分からの抜け出し $S$ を用いて梁の回転角 $\theta$ を求め，（2 1）式で計算した。

$$
\delta_{\mathrm{r}}=\theta \cdot \mathrm{L}=\left[\mathrm{S} /\left(\mathrm{d}-\mathrm{x}_{\mathrm{n}}\right)\right] \cdot \mathrm{L}
$$

$\mathrm{L}$ : 梁長さ, $\mathrm{d}$ : 有効せい, $\mathrm{x}_{\mathrm{n}}$ : 圧縮縁から中立軸 までの距離

図 11 から，計算値は実测值とよく一致していること と，全たわみのうち約 $38 \%$ （実験IIでは35～50\%）が端部 鉄筋の抜け出しによるもので，たわみに及ぼす端部鉄筋 の抜け出しの影響が大きいことが分かる。

（2）持続荷重下における端部ひび割れ幅とたわみ

a. 端部ひび割れ幅の持続載荷中の増加

図 12 に鉄筋位置側面における持続載荷開始後に増加 した端部ひび割れ幅の経時変化を示す。ひび割れ幅は持 続載荷開始後 1 日内に付着応力の緩和によって急増し, その後はコンクリートの乾燥収縮と圧縮縁コンクリート のクリープの影響を受けて緩やかに増加している。

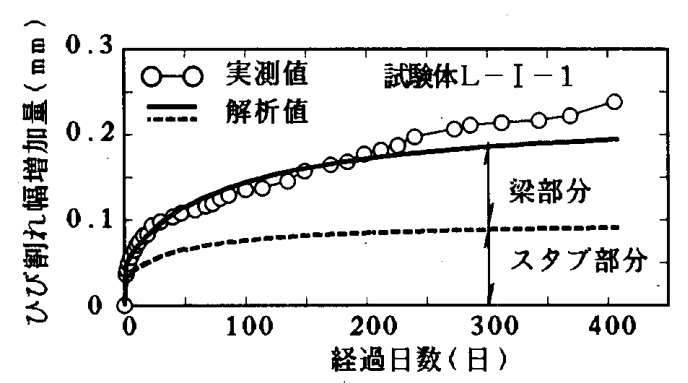

図 12 持続載荷中の端部ひび割れ幅の增加（実験 I ）

持続載荷 406 日間において $0.22 m m （ L-I-2$ は $0.24 \mathrm{~mm}$ ) 増加し，この值は初載荷時のひび割れ幅に匹敵 している。前述のように鉄筋ひずみが持続載荷 1 日後殆 ど変わらないのに，このようにひび割れ幅が増加するの はコンクリートの乾燥收縮の影響 ${ }^{11}$ によるものである。 同図中の曲線は前述の付着解析法による解析值で, 破線 は鉄筋のスタブ部からの抜け出し，実線はそれに梁部分 からの抜け出しを加えたものである。解析值はよく実測 值を捉えている。解析值によると, 持続載荷406日におい てスタブ部分からの鉄筋の抜け出しによるひび割れ幅の 増加量は，全増加量の約 $51 \%$ 占めている。

b. たわみの持続載荷中の増加

図 13 にL-I - 1 の持続載荷開始後増加したたわみ 量の経時変化を示す。眓中破線は端部鉄筋の抜け出しに よる回転たわみの増加量 $\Delta \delta_{\mathrm{r}}$, 実線は $\Delta \delta_{\mathrm{r}}$ と曲げたわ みの増加量 $\Delta \delta_{f}$ の和を表わしている。たわみは持続載荷 開始後 1 日間に鉄筋の抜け出しに伴って急増した。持続 載荷406日におけるたわみ増加量（解析值）に占める抜け 出しによるたわみ増加量の割合は $44 \%$, 長期たわみも抜 け出しの影響が大きいことがわかる。なお, 拔け出しに

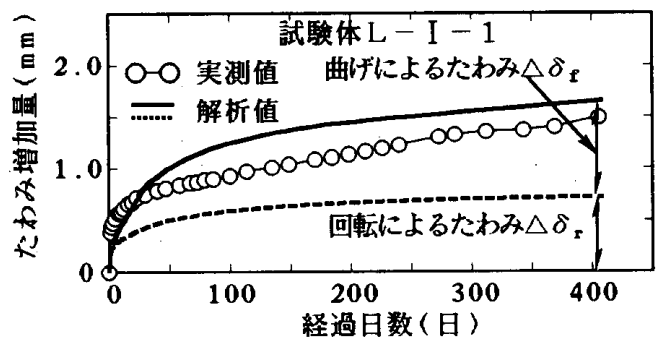

図 13 持続載荷中のたわみの増加（実験 I ） 
よる回転たわみ $\Delta \delta_{r}$ は, 初載荷時の計算方法と同じよう に（2 1) 式で計算した。曲げたわみ $\Delta \delta_{\mathrm{f}}$ は, A C I コード 13) の長期たわみの計算法によった。A C I の計算 法には断面の大きさの違いによる乾燥収縮の差異などが 考慮できない問題はあるが，解析值は実測值をほぼ捉え ている。406日間持続載荷後のたわみ（実測值）は持続載 荷開始時の約1.74倍（L-I - 2 は1.69倍）になった。

4. 4 各種要因の持続荷重下における端部鉄筋の抜け 出しによる付加たわみに及ぼす影響（実験II）

（1）端部ひび割れ幅の持続載荷中の增加

図 14 （a），（b）に実験I の各試験体の持続荷重 下における端部ひび割れ幅の増加量の経時変化を示す。 図中の記号は実測值を，曲線は前述の解析方法による解 析值を表している。解析值は実測值をよく捉えている。 ひび割れ幅は実験 I と同様に持続載荷開始後 1 日内に急 增し, その後は緩やかに增加している。前述の解析式か らも分かるように, コンクリートの乾燥収縮が大きいほ ど鉄筋の抜け出し量も大きく，持続鉄筋応力が大きいほ ど付着長が長くなり，また，付着応力の緩和も大きいた め，鉄筋の抜け出し量も大きくなる。すなわち，コンク リートの乾燥収縮が大きい試験体，あるいは端部鉄筋応

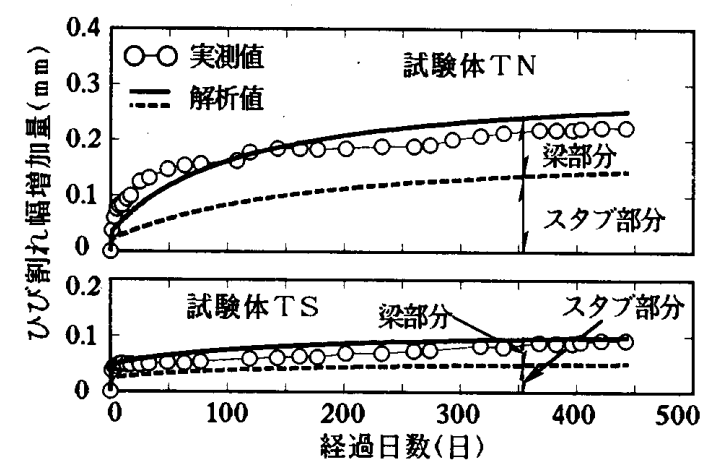

(a)

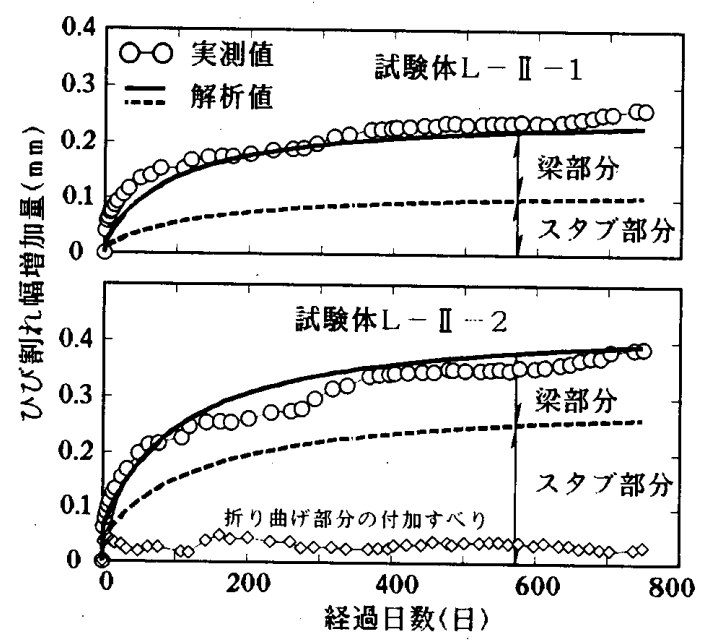

(b)

図 14 持続載荷中の端部ひび割れ幅の増加（実験II）
力の大きい試験体では持続 荷重下におけるひび割れ幅 の增加量は大きくなる。

図14（b）に示すよう に試験体 L - II - 2には図 15 に示すような折り曲げ 部の付加すべりがわずかな

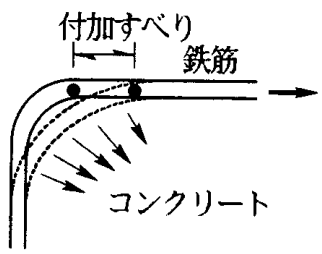

図 15 付加すべり がら現れている。ただし，その值は小さいため，鉄筋の 拔け出しの解析では無視している。

各試験体の端部ひび割れ幅の増加量 (解析値)に占め るスタブからの抜け出し量は次の通りである。持続載荷 450日において試験体 T N, T S , L - II - 1 および L II - 2 は，それぞれ $57 \% ， 52 \% ， 44 \%$ と66\%で，持続載 荷750日において試験体L－II－1およびL－II－2はそ れぞれ $46 \%$ と66\%である。

（2）たわみの持続載荷中の增加

図 16 （a），（b）に実験 II の各試験体の持続荷重 下におけるたわみの增加量の経時変化を示す。図中の曲 線は前述の解析方法を用いた解析值を表している。解析 值は実測值をほぼ捉えている。全体に，端部ひび割れ幅 の増加量と同様に, 乾嬠収縮量の大きい試験体および端 部鉄筋持続応力の大きい試験体は鉄筋の抜け出しが大き

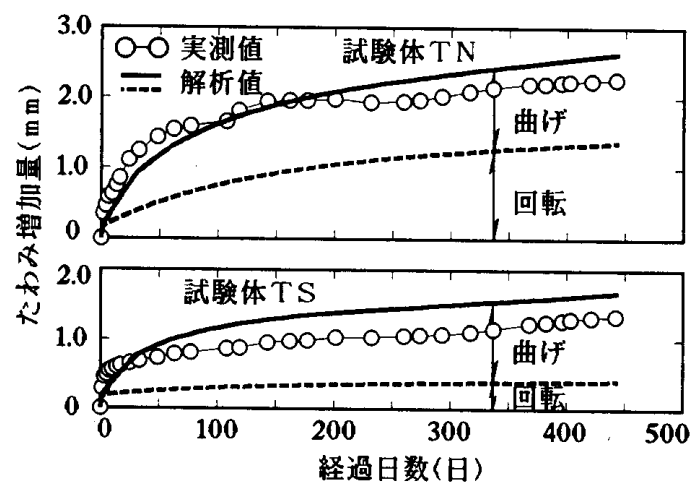

(a)

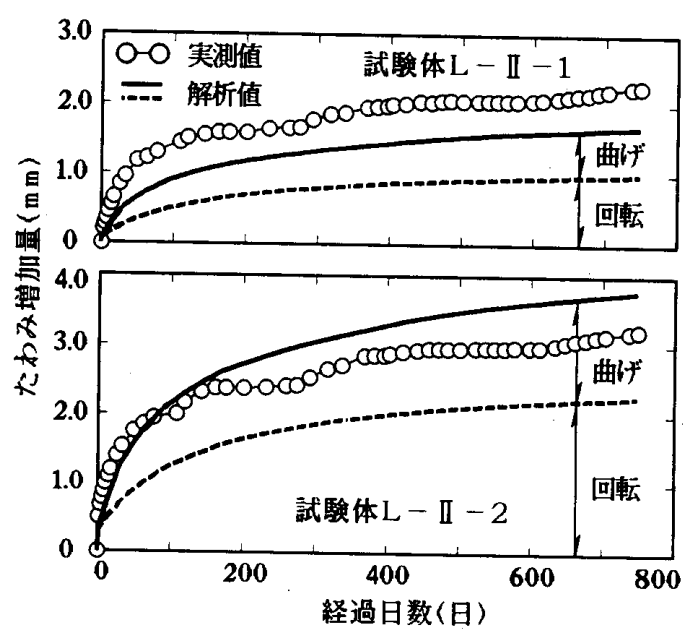

(b)

図 16 持続載荷中のたわみの増加（実験II） 
いため, たわみの増加量も大きい。持続載荷450日におい て試験体 T N, T S , L-II-1，L-II-2のスタブからの 抜け出しによる付加たわみの増加量（解析值） $\Delta \delta_{\mathrm{r}}$ はそ れそれ1.3，0.4，0.9，2.1m盀で，乾燥収縮が制御されてい ない試験体 $(\mathrm{TN})$ $) \Delta \delta_{\mathrm{r}}$ は制御された試験体 ( T S ) の約 3 倍, 端部鉄筋持続応力の大きい試験体（L-II-2） の $\Delta \delta_{\mathrm{r}}$ は小さい試験体（L-II-1）の約 2 倍である。

各試験体のたわみの増加量（解析值）に占めるスタブ からの抜け出しによる付加たわみは次の通りで, 鉄筋抜 け出しの影響が大きいことが示されている。持続載荷450 日において試験体 T N, T S , L - II - 1 および L - II ー2 は,それそれ $52 \%, 24 \%, 60 \%$ と $61 \%$ で, 持続載荷 750日において試験体L－II－1 およびL－II－2 はそれ それ $59 \%$ と60\%である。なお，鉄筋の抜け出しによる付 加たわみ $\delta_{\mathrm{r}}$ は(21)式から理解されるように中立軸深さす なわち部材有効せい(d)に大きく影響される。本試験体の $\mathrm{d}$ は15cmで一般のはりよりはかなり小さく，スラブより は少し大きい。したがって, 一般のスラブの $\delta_{r}$ は本実験 の結果と同程度かそれ以上で, 通常のはりの ${ }_{\mathrm{r}}$ は本実験 の結果より小さくなることが推測される。また，450日間 持続載荷後の試験体 T N, T S のたわみ（実測值）は持 続載荷開始時の約 1.80 と1.53倍で, 乾燥収縮が大きい程 増加率は大きく, 750日間持続載荷後の試験体 L - II $1, \mathrm{~L}-\mathrm{II}-2$ のたわみは持続載荷開始時の初期たわみ の約2.82と1.76倍で, 荷重が小さい程初期たわみが小さ く増加率は大きくなった。

\section{5. 結論}

以上の付着解析および部材有効せい $15 \mathrm{~cm} の$ 片持ち梁の 持続載荷実験から得られた主な結果をまとめると次のよ うになる。

（1）曲げモーメント勾配がある部材にも適用できるよ うな， R C引張材両端に大きさの異なる引張力が作用す る付着解析モデルを提案した。これを用いて, 持続荷重 を受ける片持ちはりの鉄筋ひずみ分布およびその抜け出 し量（ひび割れ幅）を算定することができた（図 8 , 図 9 , 図 12 , 図 14 )。

（2）片持梁の端部ひび割れ幅は, スタブ部分と梁部分 からの鉄笳抜け出しからなり, 持続載荷後 1 日間に付着 応力の緩和によって急増し，その後は主としてコンク リートの乾暞収縮に応じて緩やかに増加する。本実験の 場合, スタブ部分からの抜け出しの持続載荷後増加した 端部ひび割れ幅に占める割合は46〜66\%であった。

（3）片持梁のたわみは, 梁の曲げたわみとスタブ部分 の抜け出しによる付加回転たわみからなる。本実験の場 合, 付加回転たわみは, 初載荷時では全たわみ量の30 $50 \%$, 持続載荷中では44 61\%（コンクリートの乾燥収縮 が制御された場合を除く）と大きな割合を占めている。
本研究は文部省科学研究費補助金 (一般 C : 代表者 大野義

照) の交付を受けた研究の一部として実施したものである。

\section{考文祆}

1）土橋由造，井野 智：大たかみを持つ鉄筋コンクリート障害床 スラプの実態調查とその対策，日本建築学会論文報告集， N0.272, pp.41 51，1978.10.

2）武田寿一，中根 㳯, 小楖光生 : 鉄筋コンクリート床スラプの 長期たわみに関する研究，日本建学学会論文報告集，№.365， pp.165 173, 1986.7.

3）日本建築学会 : 鉄筋コンクリート構造計算規淮・同解説, pp.506 512, 1988.

4) 小森清司, 東 洋一 : 鉄筋コンクリート帯スラフの長期たわみ に関する研究 (2)，日本建築学会大会講演梗概集（中国）， 構造系II-II, pp.1837〜1838，1977.10.

5) 武田寿一, 高橋久雄, 小柳光生 : 床スラプの長期たかみに関す る研究, コンクリートエ学論文, vol.21, No.9, pp.115〜124, 1983.9.

6）岩原昭次：長期設計荷重下におけるR C 造スラプの鉄筋の抜け 出しに関する解析的研究, 日本建策学会構造系論文報告集, №.400, pp.45 57, 1989.6 .

7）岩原昭次 : 使用荷重下における鉄筋コンクリート床スラプの長 期曲け問題に対する解析法に関する研究（第一報 ひび割れを 生した一方向スラフの瞬時曲け問題に対する解析法），日本建 築学会構造系論文報告集, N0.415, pp.63〜 73，1990.9.

8）井野智，伊藤正義，杉野目章，植松武是：鉄筋コンクリート床 スラプ端部上ば鉄筋定着部の伸びによる付加たわみ概算法， コンクリートエ学年次論文報告集, 第14巻, 第 2 号, pp.149 $155,1992.6$.

9 ）岡田克也：両端固定 R C 部材の上端鉄筋の抜け出しによる付加 たわみ概算法, 日本建築学会大会講演梗概集（関東），C粠造 II , pp.159 160, 1993.9 .

10）六車 熙, 森田司郎, 富田幸次郎：墭とコンクリートの付着に 関する基整的研究（付着応力分布について），日本建築学会論 文報告集, №.131，pp.1 8, 1967.1.

11）大野義照，李 振宝，鈴木計夫 : 持続荷重下における異形鉄筋 とコンクリート間の付着応力〜すべり関係, 日本建築学会構造 系論文報告集, No.459, 1994.5 .

12 ) Building Code Requirements for Reinforoed Concrete (ACl318-89) and Commentaty-ACI 318R-89, p.93 1989.

13）前出 12 ) p.94

14）鍋沢斤吾, 鈴木幛夫, 大野義照, 李振宝, 大田崇士 : 鉄筋コン クリート片持ちはりの長期たわみに関する研究, 日本建築学会 大会蔧演梗概集（北陸），C棧造II，pp.289〜290，1992.8.

15）李 振宝, 鈴木計夫, 大野義照: 常時荷重域における鉄筋コン クリート部材の付着解析, 日本建学会大会講演梗概集(北

陸），C構造II，pp.949 950，1992.8.

(1994年 5 月 10 日原稿受理, 1994 年10月25日探用決定) 